\title{
Interaction of type 2 diabetes mellitus with Chromosome 9p21 rs10757274 polymorphism on the risk of myocardial infarction: a case-control study in Chinese population
}

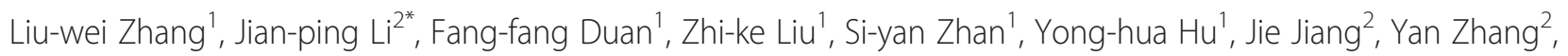
Yong Huo ${ }^{2}$ and Da-fang Chen ${ }^{1 *}$

\begin{abstract}
Background: Myocardial infarction (MI) is a serious complication of Coronary Artery Disease (CAD). Previous studies have identified genetic variants on chromosome 9p21 and 6p24 that are associated with CAD, but further studies need to be conducted to investigate whether these genetic variants are associated with the pathogenesis of MI. We therefore performed this study to assess the association between the risk of MI and SNP rs10757274 on chromosome 9p21 and SNP rs6903956 on chromosome 6p24, and to explore the gene-environment interactions in a Chinese population.

Methods: A hospital-based case-control study, consisting of $502 \mathrm{Ml}$ patients and 308 controls, was conducted in a Chinese population. Demographic, behavioral information and clinical characteristics were collected, and genotyping of the two SNPs was performed using single base primer extension genotyping technology. The unconditional logistic regression (ULR) method was adopted to assess the association of the two SNPs with Ml risk. Both generalized multifactor dimensionality reduction (GMDR) and ULR methods were applied to explore the effect of gene-environment interactions on the risk of Ml.

Results: After adjusting for covariates, it was observed that SNP rs10757274 on chromosome 9p21 was significantly associated with Ml. Compared with subjects carrying the AA genotype, subjects carrying the GA or GG genotypes had a higher Ml risk $\left(\mathrm{OR}_{a}=1.52,95 \% \mathrm{Cl}: 1.06-2.19, p_{a}=0.0227 ; \mathrm{OR}_{a}=2.40,95 \% \mathrm{Cl}: 1.51-3.81, p_{a}=0.0002\right.$, respectively). Furthermore, a two-factor gene-environment interaction model of CDKN2A/B (rs10757274) and type 2 diabetes mellitus (T2DM) was identified to be the best model by GMDR ( $p=0.0107$ ), with a maximum prediction accuracy of 59.18\%, and a maximum Cross-validation Consistency of 10/10. By using the ULR method, additive interaction analysis found that the combined effect resulted in T2DM-positive subjects with genotype $\mathrm{GG} / \mathrm{GA}$ having an Ml risk 4.38 times that of T2DM-negative subjects with genotype AA ( $\left.\mathrm{OR}_{\text {add }}=4.38,95 \% \mathrm{Cl}: 2.56-7.47, p_{\text {add }}<0.0001\right)$.

Conclusions: These results show that gene polymorphism of CDKN2A/B (rs10757274) is associated with Ml risk in a Chinese population. Furthermore, T2DM is likely to have an interaction with CDKN2A/B (rs10757274) that contributes to the risk of $\mathrm{Ml}$.
\end{abstract}

\footnotetext{
*Correspondence: lijianping@medmail.com.cn; dafangchen@bjmu.edu.cn

${ }^{2}$ Department of Cardiology, Peking University First Hospital, Beijing 100034,

China

'Department of Epidemiology and Biostatistics, School of Public Health,

Peking University Health Science Center, Beijing 100191, China
} 


\section{Background}

It has been reported that the global endemic of Coronary Artery Disease (CAD) is the leading cause of morbidity and mortality worldwide, due to serious complications such as myocardial infarction (MI) [1,2]. Most researchers agree that, similarly to other complex diseases, multiple environmental factors, genetic factors and gene-environment interactions play important roles in determining the onset and development of CAD/MI [3]. There are many wellrecognized environmental risk factors such as smoking, physical activity and body mass index (BMI). Genetic factors have also been considered to be substantial risk contributors to the pathogenesis of CAD/MI $[4,5]$. Although previous studies have shown that the heritability of CAD ranges from approximately 40 to $60 \%$, the genetic mechanism underlying the inherited component of $\mathrm{CAD} / \mathrm{MI}$ is still not fully characterized [6].

In the past decade, there have been many studies on linkage and candidate gene association, however, these have only identified a limited number of genetic variants involved in the pathogenesis of CAD/MI. Genome-wide association studies (GWAS) have been a new approach since the completion of the Human Genome Project and the International HapMap Project, and have provided improved resolution in identifying genetic factors in relation to complex diseases. To date, many genome-wide studies have revealed that several genomic regions are strongly associated with an increased risk of CAD/MI [7-14], and it has been generally accepted that the association between genetic variants on chromosome 9p21 and the risk of CAD is the most robustly replicated finding in different ethnic populations [15-18]. However, several other studies have shown inconsistent results when the association between these genetic variants and MI was examined [19,20]. Recently, a Chinese GWAS reported that chromosome $6 \mathrm{p} 24$ contains a novel susceptibility locus associated with CAD [14]. Some previous single studies have also suggested that genetic variants associated with cardiovascular disease might interact with hypertension or glycemic control [21,22]. Therefore, we chose to study SNP rs10757274 on chromosome 9p21 and SNP rs6903956 on chromosome 6p24, to identify the association between these two susceptible genes and the risk of MI, and to explore gene-environment interactions in a Chinese population.

\section{Methods}

\section{Study population}

This project was designed as a hospital-based case-control study. Between June 2012 and May 2013, a total of 810 consecutive unrelated adult patients at Peking University First Hospital (Beijing, China) were enrolled in the study. Of these subjects, 502 patients undergoing coronary angiography for suspected or known coronary atherosclerosis were diagnosed with $\mathrm{MI}$ according to the universal definition of myocardial infarction [23], while 308 subjects were considered as the control group, who underwent coronary angiography for other reasons (mainly valvular heart disease) and had completely normal coronary arteries. Quanto software was used to measure the statistical power of this study; according to the frequencies of the minor allele (listed on NCBI) and the genetic effects that have been reported for these two SNPs, the statistical power of this study based on the current sample size is more than 0.90 . The study was approved by the Ethics Committee of the Peking University Health Science Center, and all the subjects provided written informed consent for participation.

\section{Information collection}

Demographic, behavioral information and clinical characteristics were collected from physicians and hospital records, including age, gender, ethnicity, smoking and drinking habits and some medical history information. A smoking habit was defined as current active smokers or those with a smoking history of at least 10 packs per year, while a drinking habit was defined as consuming more than $50 \mathrm{~g}$ of alcohol per week for at least 6 months. Weight and height were measured when the subjects were lightly clothed and barefoot, and the BMI was calculated as the weight divided by the square of the height $\left.\left(\mathrm{kg} / \mathrm{m}^{2}\right)\right)$. Overnight fasting blood samples were obtained from all participants, and measurements of the plasma concentrations of glucose, total cholesterol (TC, $\mathrm{mmol} / \mathrm{L}$ ), low density lipoprotein cholesterol (LDL-C, $\mathrm{mmol} / \mathrm{L}$ ), high density lipoprotein cholesterol (HDL-C, mmol/L) and triglyceride (TG, $\mathrm{mmol} / \mathrm{L}$ ) were conducted in the clinical laboratory of the Peking University First Hospital according to the standard biochemical methods. Combined with laboratory findings, type two diabetes mellitus (T2DM) was diagnosed according to the WHO diagnostic criteria from 1999 [24]; hypertension was defined as systolic blood pressure $\geq 140 \mathrm{mmHg}$ and/or diastolic blood pressure $\geq 90 \mathrm{mmHg}$ based on the average of two separate measurements, or current antihypertensive treatment; hyperlipidemia was diagnosed as fasting total cholesterol $\geq 200 \mathrm{mg} / \mathrm{dL}$ or low-density lipoprotein cholesterol $\geq 130 \mathrm{mg} / \mathrm{dL}$.

\section{DNA preparation}

EDTA anti-coagulated blood samples were drawn from every participant, and genomic DNA was extracted from the participants' peripheral blood leucocytes by using the protein precipitation method following standard procedures. Each DNA sample was quantified using a Nanophotometer (Implen, Germany) and was diluted to a final concentration of $50 \mathrm{ng} / \mathrm{uL}$. 


\section{SNP genotyping}

Genotyping of two SNPs (rs6903956 and rs10757274) was performed using the single base primer extension genotyping technology with the GenomeLab SNPstream genotyping system (Beckman Coulter Inc, Fullerton, CA, USA) following the manufacturer's protocol [25]. Both of the SNPs had a call rate of greater than $95 \%, 10 \%$ of the blind duplicate samples were genotyped repeatedly and the rate of consistency was $100 \%$.

\section{Statistical analysis}

The descriptive and association analyses were performed using the SAS 9.1 software (SAS Institute Inc., Cary, NC). The continuous variables were shown as Mean $\pm \mathrm{SD}$, a two-sample $t$-test was adopted to compare their means. The comparison of categorical variables and testing of the Hardy-Weinberg Equilibrium (HWE) at each polymorphic locus in the control group was conducted using Pearson's $\chi^{2}$ test. Unconditional logistic regression (ULR) was performed to estimate the association (Odds ratios (ORs) and 95\% confidence intervals (CIs)) between individual polymorphisms and MI, adjusting for potential confounders, including gender, age, ethnicity, BMI, smoking and drinking habits. High dimensional gene-environment interactions were examined using the generalized multifactor dimensionality reduction method (GMDR, version 0.7, obtained from http://www.medicine.virginia.edu/clinical/ departments/psychiatry/sections/neurobiologicalstudies/ genomics/gmdr-software-request) [26], adjusting for age, gender, ethnicity, BMI, smoking and drinking habits as covariates. GMDR is a nonparametric method reducing high-dimensional data into one dimension. In this study, one- to five-factor models were constructed and the model with the highest prediction accuracy was defined as the "best model". If the model was considered to be significant using the sign statistical test $(p<0.05)$, then a 1000 times permutation test was performed to validate the results. One dimensional multiplicative interaction was detected by ULR, adjusting for the potential confounders mentioned above. One dimensional additive interaction was estimated using the "Biological interaction calculating Excel" provided by Andersson et al. [27]. For two dichotomized risk factors, let $\mathrm{OR}_{01} / \mathrm{OR}_{10}$ represent exposure of each risk factor alone, let $\mathrm{OR}_{11}$ represent exposure of both risk factors, and let $\mathrm{OR}_{00}$ represent absence of both risk factors, which was used as the reference category. Three statistical indicators were calculated: relative excess risk of interaction $\left(\mathrm{RERI}=\mathrm{OR}_{11}-\left(\mathrm{OR}_{01}+\mathrm{OR}_{10}-1\right)\right)$, attributable proportion of interaction (API $=\mathrm{RERI} / \mathrm{OR}_{11}$ ), and the synergy index $\left(\mathrm{S}=\left(\mathrm{OR}_{11}-1\right) /\left[\left(\mathrm{OR}_{01}-1\right)+\left(\mathrm{OR}_{10}-1\right)\right]\right)$, along with their $95 \%$ CIs, to measure the additive interaction. If the $95 \%$ CIs of RERI and API did not include 0 and the $95 \% \mathrm{CI}$ of the $\mathrm{S}$ index did not include 1, it can be considered that an additive interaction exists.

\section{Results}

Demographic, behavioral information and clinical characteristics of participants

A total of 810 unrelated Chinese subjects were enrolled in this study. The minimum and maximum ages among the participants were 28 and 88 , respectively. The average age of the 502 cases was $(63.66 \pm 11.57)$ years, and the average age of the 308 controls was $(61.87 \pm 10.39)$ years. $64.92 \%$ of participants were male and $35.08 \%$ were female. The distributions of demographic, behavioral information and clinical characteristics of the subjects are listed in Table 1. There were no significant differences between the MI group and the control group in terms of mean BMI and distributions of ethnicity, hypertension and hyperlipidemia, while the mean age and frequencies of male gender, T2DM-positive, and smoking and drinking habits-positive were significantly higher in MI patients than in controls.

\section{Association analysis of genetic polymorphisms with MI}

Two SNPs, ADTRP (rs6903956) and CDKN2A/B (rs107 57274) were studied in our association analysis. Both of their genotype distributions in the control group conformed to the HWE $\left(\chi^{2}=2.756, p=0.097 ; \chi^{2}=0.968\right.$, $p=0.325$; respectively), which indicated these participants were from a homogeneous group. The genotype distributions of the two SNPs between MI patients and controls and their association with MI risk are available in Table 2, while the univariate associations between each of the two SNPs and the clinical characteristics listed in Table 1 for cases and controls are included in the Additional file 1: Table S1 and S2. Taking the subjects carrying the GG genotype for ADTRP (rs6903956) as a reference, the subjects carrying genotype AA/GA showed an increased risk of MI (OR = 1.51, 95\% CI:1.01-2.23, $p=0.0423)$, but after adjusting for confounding factors including age, gender, ethnicity, BMI, smoking and drinking habits, the association between ADTRP (rs6903956) and MI risk was insignificant $(\mathrm{OR}=1.49,95 \% \mathrm{CI}: 0.97-2.29, p=0.0678)$. According to the genetic effect and minor allele frequency of rs6903956 observed in this study, the statistical power based on the current sample size is 0.73 . For CDKN2A/B (rs10757274), both before and after adjusting for confounding factors mentioned above, the subjects carrying GA or GG genotypes were all associated with MI risk $\left(\mathrm{OR}_{\mathrm{a}}=1.52,95 \%\right.$ CI:1.06-2.19, $p_{a}=0.0227$; $\mathrm{OR}_{\mathrm{a}}=2.40$, 95\% CI:1.51-3.81, $p_{a}=0.0002$; respectively), compared with subjects with the AA genotype. For rs 10757274, the statistical power based on the current sample size is 0.97 .

\section{Gene-environment interactions analysis}

First, GMDR was used to explore the gene-environment interactions. ADTRP (rs6903956), CDKN2A/B (rs10757274) 
Table 1 Demographic, behavioral information and clinical characteristics of participants

\begin{tabular}{|c|c|c|c|c|}
\hline \multirow[t]{2}{*}{ Variable } & \multicolumn{2}{|c|}{ Variable frequencies (\%) } & \multirow[b]{2}{*}{$t / x^{2}$} & \multirow[b]{2}{*}{$p$-value } \\
\hline & $\begin{array}{l}\text { Controls } \\
(\mathrm{N}=308)\end{array}$ & $\begin{array}{c}\text { MI patients } \\
(\mathrm{N}=502)\end{array}$ & & \\
\hline Age & $61.87 \pm 10.39$ & $63.66 \pm 11.57$ & 2.2823 & 0.0228 \\
\hline BMI $\left(\mathrm{kg} / \mathrm{m}^{2}\right)$ & $25.84 \pm 3.53$ & $25.73 \pm 3.09$ & 0.4673 & 0.6404 \\
\hline \multicolumn{5}{|l|}{ Gender } \\
\hline Male & 47.73 & 77.09 & 73.2707 & $<.0001$ \\
\hline Female & 52.27 & 22.91 & & \\
\hline \multicolumn{5}{|l|}{ Ethnicity } \\
\hline Chinese Han & 94.48 & 96.81 & 2.6567 & 0.1031 \\
\hline Ethnicity minority & 5.52 & 3.19 & & \\
\hline \multicolumn{5}{|l|}{ Smoking habit } \\
\hline No & 63.96 & 36.65 & 57.1381 & $<.0001$ \\
\hline Yes & 36.04 & 63.35 & & \\
\hline \multicolumn{5}{|l|}{ Drinking habit } \\
\hline No & 74.68 & 61.75 & 14.3438 & 0.0002 \\
\hline Yes & 25.32 & 38.25 & & \\
\hline \multicolumn{5}{|l|}{ T2DM } \\
\hline No & 75.97 & 61.35 & 18.4275 & $<.0001$ \\
\hline Yes & 24.03 & 38.65 & & \\
\hline \multicolumn{5}{|l|}{ Hypertension } \\
\hline No & 35.71 & 32.07 & 1.1376 & 0.2862 \\
\hline Yes & 64.29 & 67.93 & & \\
\hline \multicolumn{5}{|l|}{ Hyperlipidemia } \\
\hline No & 60.06 & 61.55 & 0.1778 & 0.6732 \\
\hline Yes & 39.94 & 38.45 & & \\
\hline
\end{tabular}

and clinical characteristics (T2DM, hypertension and hyperlipidemia) were included in the gene-environment interactions analysis, adjusting for age, gender, ethnicity, BMI, and smoking and drinking habits as covariates. The results of the GMDR analysis for one-factor to five-factor models are shown in Table 3. Among these results, the two-factor interaction model of CDKN2A/B (rs10757274) and T2DM was identified to be the best model, with a maximum prediction accuracy of $59.18 \%$, and a maximum Cross-validation Consistency (CVC) of 10/10. This model was identified as significant using the sign test $(p=0.0107)$ and validated by a 1000 times permutation test $(p<0.001)$. These results indicate that a potential gene-environment interaction is likely to exist between T2DM and CDKN2A/B (rs10757274) affecting MI risk in this study.

Second, to further reveal the potential gene-environment interaction mentioned above, ULR analysis was conducted to explore the possible multiplicative or additive geneenvironment interactions between T2DM and CDKN2A/B (rs10757274) affecting MI risk. As shown in Table 4, there were no gene-environment multiplicative interactions between T2DM and CDKN2A/B (rs10757274) affecting MI risk $\left(\mathrm{OR}_{\text {multi }}=1.63,95 \% \mathrm{CI}: 0.78-3.44, p_{\text {multi }}=0.197\right)$. After adjusting for age, gender, ethnicity, BMI, smoking and drinking habits as covariates, T2DM-negative subjects with the genotype GG/GA had a MI risk of 1.60 times that of T2DM-negative subjects carrying the genotype AA $\left(\mathrm{OR}_{\mathrm{add}}=1.60,95 \% \mathrm{CI}: 1.04-2.46\right)$, and it was statistically significant $\left(p_{\text {add }}=0.0329\right)$; T2DM-positive subjects with genotype AA had a MI risk of 1.68 times that of T2DM-negative subjects carrying genotype $\mathrm{AA}\left(\mathrm{OR}_{\mathrm{add}}=\right.$ $1.68,95 \%$ CI:0.92 - 3.08), but it was not statistically significant $\left(p_{\text {add }}=0.0943\right)$. The combined effect resulted in T2DM-positive subjects with genotype GG/GA having an MI risk of 4.38 times that of T2DM-negative subjects carrying genotype AA $\left(\mathrm{OR}_{\mathrm{add}}=4.38,95 \% \mathrm{CI}: 2.56-7.47\right)$, and this was statistically significant $\left(p_{\text {add }}<0.0001\right)$. Because the $95 \%$ CIs of RERI and API did not include 0 , and the $95 \% \mathrm{CI}$ of $\mathrm{S}$ did not include 1 (RERI $=2.10,95 \%$ CI:0.18-4.03; API $=0.48,95 \%$ CI:0.19-0.77; and S $=$ 2.65, 95\% CI:1.01 - 6.94, respectively), it can be considered that an additive gene-environment interaction exists between T2DM and CDKN2A/B (rs10757274) affecting the risk of MI.

Table 2 Association analysis of genetic polymorphisms with MI risk

\begin{tabular}{|c|c|c|c|c|c|c|c|c|c|}
\hline \multirow{2}{*}{$\begin{array}{c}\text { Chromosome } \\
\text { location }\end{array}$} & \multirow{2}{*}{$\begin{array}{l}\text { Closest } \\
\text { gene }\end{array}$} & \multirow[t]{2}{*}{ SNPs } & \multirow[t]{2}{*}{ Genotypes } & \multicolumn{2}{|c|}{ Genotype frequencies (\%) } & \multicolumn{2}{|c|}{ Without adjustment } & \multicolumn{2}{|c|}{ With adjustment } \\
\hline & & & & Controls $(\mathrm{N}=308)$ & MI patients $(\mathrm{N}=502)$ & OR $(95 \% \mathrm{Cl})$ & $p$ & $\mathrm{OR}_{\mathrm{a}}(95 \% \mathrm{Cl})$ & $p_{\mathrm{a}}$ \\
\hline \multirow[t]{4}{*}{$6 \mathrm{P} 24$} & ADTRP & rs6903956 & GG & 85.23 & 79.30 & reference & & & \\
\hline & & & GA & 13.40 & 18.74 & $1.50(1.00,2.27)$ & 0.0525 & $1.55(0.99,2.43)$ & 0.0556 \\
\hline & & & AA & 1.37 & 1.96 & $1.53(0.47,5.03)$ & 0.4813 & $1.04(0.30,3.59)$ & 0.9522 \\
\hline & & & $\mathrm{AA} / \mathrm{GA}$ & 14.78 & 20.70 & $1.51(1.01,2.23)$ & 0.0423 & $1.49(0.97,2.29)$ & 0.0678 \\
\hline \multirow[t]{4}{*}{ 9P21 } & CDKN2A/B & rs10757274 & AA & 32.78 & 23.54 & reference & & & \\
\hline & & & GA & 51.32 & 52.52 & $1.43(1.02,1.99)$ & 0.0374 & $1.52(1.06,2.19)$ & 0.0227 \\
\hline & & & GG & 15.89 & 23.94 & $2.10(1.37,3.22)$ & 0.0007 & $2.40(1.51,3.81)$ & 0.0002 \\
\hline & & & $\mathrm{GG} / \mathrm{GA}$ & 67.22 & 76.46 & $1.58(1.15,2.18)$ & 0.0045 & $1.72(1.22,2.43)$ & 0.0020 \\
\hline
\end{tabular}

a: Adjusting for age, gender, ethnicity, BMl, smoking and drinking habits as covariates. 
Table 3 GMDR models of gene-environmental interactions on MI risk

\begin{tabular}{lcccc}
\hline Models $^{\mathbf{a}}$ & $\begin{array}{c}\text { Prediction } \\
\text { accuracy }\end{array}$ & CVC & $\boldsymbol{p}_{\text {sign }}$ & $\boldsymbol{p}_{\text {perm }}$ \\
\hline T2DM & 0.5815 & $10 / 10$ & 0.0010 & $<0.001$ \\
T2DM, rs10757274 & 0.5918 & $10 / 10$ & 0.0107 & $<0.001$ \\
T2DM, rs10757274, rs6903956 & 0.5796 & $10 / 10$ & 0.0107 & $<0.001$ \\
T2DM, hyperlipidemia, & 0.5815 & $9 / 10$ & 0.0547 & $<0.001$ \\
rs10757274, rs6903956 & & & & \\
$\begin{array}{l}\text { T2DM, hyperlipidemia, hypertension, } \\
\text { rs10757274, rs6903956 }\end{array}$ & 0.5692 & $10 / 10$ & 0.0547 & 0.008 \\
\end{tabular}

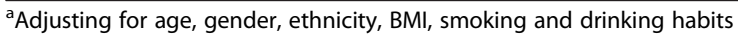
as covariates.

$p_{\text {sign }} p$-value from sign test.

$p_{\text {perm: }} p$-value from 1000 times permutation test.

\section{Discussion}

Due to the fact that MI is the main complication of CAD and both of these diseases share common risk factors, both genetic variants and environmental risk factors associated with CAD are expected candidates affecting the risk of MI. In this case-control study, we chose two previously reported SNPs representing the genetic variants on 9p21 and 6p24 to investigate the association with MI. Our results indicate that a genetic variant of CDKN2A/B (rs10757274) on 9p21 is associated with MI after adjusting for conventional confounding factors, which consistently supports former results $[10,28,29]$. Further gene-environment interactions for ADTRP (rs6903956), CDKN2A/B (rs10757274), hypertension, dyslipidemia and T2DM were explored by GMDR and ULR methods, and the results from GMDR indicate that a gene-environment interaction is likely to exist between CDKN2A/B (rs10757274) and T2DM affecting the risk of MI. Further analytic results from ULR consistently support the existence of potential additive gene-environment interactions between CDKN2A/B (rs10757274) and T2DM, with a combined effect of increasing the risk of MI for T2DM- positive subjects with genotype GG/GA by 4.38 times that of T2DM-negative subjects carrying genotype AA. It had been previously reported that diabetes is a positive factor contributing to CAD/MI [30,31]. T2DM, accounting for the majority of forms of diabetes, has also been considered a common disorder and an important risk factor for cardiovascular disease [32]. Recently, a report in a Chinese population also found that another genomic variant on $9 \mathrm{p} 21$ is associated with a risk of T2DM [33]. This is thought to be due to the CDKN2A and CDKN2B genes in this genomic region inhibiting CDK4 and CDK6, which has been demonstrated to influence $\beta$ cell proliferation and mass, eventually leading to diabetes [34-36]. Meanwhile, a study published in 2008 reported an interaction between poor glycemic control and a 9p21 variant that increased the risk of CAD in T2DM [21]. Therefore, it is reasonable to consider that CDKN2A/B (rs10757274) not only increases the risk of MI, but also enhances the effects of T2DM on the risk of MI in this study.

In contrast to CDKN2A/B (rs10757274), we found that the genetic variant of ADTRP (rs6903956) on 6p24 was not associated with MI after adjusting for conventional confounding factors, which is inconsistent with recent research results reported in a Japanese population [37]. To our knowledge, only this solo Japanese research report has investigated the association between ADTRP (rs6903956) and MI to date, and the risk allele identified in this Japanese study differs from our study and two other studies conducted in Han Chinese and Japanese populations [14,38]. Most former studies have focused on the identification of associations between ADTRP and CAD, but the results are controversial even in the same racial population $[14,39,40]$. It has been indicated that the underlying mechanism is due to regulation of the mRNA expression of the tissue factor pathway inhibitor (TFPI) by the ADTRP gene. Decreased TFPI expression would result in an increased rate of thrombosis and thus increase the risk of CAD [41]. Therefore,

Table 4 Multiplicative and additive gene-environmental interactions analysis between T2DM and CDKN2A/B (rs10757274) on MI risk

\begin{tabular}{|c|c|c|c|c|c|c|c|}
\hline \multirow[b]{2}{*}{ Genotype } & \multirow[b]{2}{*}{ T2DM } & \multicolumn{2}{|c|}{ Frequencies (\%) } & \multirow[b]{2}{*}{$\mathrm{OR}_{\text {add }}{ }^{\mathrm{a}}(95 \% \mathrm{Cl})$} & \multirow[b]{2}{*}{$p_{\text {add }}$} & \multirow[b]{2}{*}{$\mathrm{OR}_{\text {multi }}{ }^{\mathrm{a}}(95 \% \mathrm{Cl})$} & \multirow[b]{2}{*}{$p_{\text {multi }}$} \\
\hline & & Controls $(\mathrm{N}=308)$ & MI patients $(\mathrm{N}=502)$ & & & & \\
\hline rs10757274 & & & & & & $1.63(0.78,3.44)$ & 0.197 \\
\hline AA & No & 22.52 & 12.67 & reference & & & \\
\hline GG/GA & & 53.31 & 48.69 & $1.60(1.04,2.46)$ & 0.0329 & & \\
\hline $\mathrm{AA}$ & Yes & 10.26 & 10.87 & $1.68(0.92,3.08)$ & 0.0943 & & \\
\hline GG/GA & & 13.91 & 27.77 & $4.38(2.56,7.47)$ & $<0.0001$ & & \\
\hline RERI & & & & $2.10(0.18,4.03)$ & & & \\
\hline API & & & & $0.48(0.19,0.77)$ & & & \\
\hline S & & & & $2.65(1.01,6.94)$ & & & \\
\hline
\end{tabular}

${ }^{a}$ Adjusting for age, gender, ethnicity, BMI, smoking and drinking habits as covariates. 
further studies are needed to completely reveal whether genetic variants on $6 \mathrm{p} 24$ are associated with the risk of MI.

There are inevitably some limitations to this study. First, as our study is based on a case-control design, it was difficult to avoid recall bias completely, and the results should be confirmed in prospective cohort studies. Second, our study investigated only a limited number of genetic variants related to MI, whereas many other genes and SNPs have been reported to contribute to MI susceptibility. Therefore, this study is not sufficient to evaluate genetic susceptibility to MI, and it would be useful for further studies to investigate more genetic polymorphisms associated with MI.

\section{Conclusion}

In conclusion, the results of this study suggest that a gene polymorphism of CDKN2A/B (rs10757274) is associated with $\mathrm{MI}$ risk in a Chinese population. Furthermore, T2DM is likely to interact with CDKN2A/B (rs10757274) and contribute to the risk of MI.

\section{Additional file}

Additional file 1: Table S1. Univariate associations between rs6903956 and the characteristics listed in Table 1 for cases and controls. Table S2. Univariate associations between rs10757274 and the characteristics listed in Table 1 for cases and controls.

\section{Abbreviations}

ULR: Unconditional logistic regression; GMDR: Generalized multifactor dimensionality reduction; CAD: Coronary Artery Disease; MI: Myocardial infarction; T2DM: Type two diabetes mellitus; BMI: Body mass index; GWAS: Genome-wide association studies; HWE: Hardy-Weinberg Equilibrium; ORs: Odds ratios; Cls: Confidence intervals.

\section{Competing interests}

The authors declare that they have no competing interests.

\section{Authors' contributions}

LZ carried out the experiments, performed the data analysis and drafted the manuscript. DC, JL, YH, SZ and YH conceived and designed the study and helped to draft the manuscript. JJ and $Y Z$ participated in the recruitment of subjects and acquisition of data. FD, ZL participated in the genotyping and interpretation of the data. All authors read and approved the final manuscript.

\section{Acknowledgements}

We acknowledge that this study was supported by the National Natural Science Foundation of China (81172768). We also need to thank the staff of the Department of Cardiology of Peking University First Hospital for their support in recruiting the study subjects.

Received: 12 June 2014 Accepted: 18 November 2014 Published: 27 November 2014

\section{References}

1. Go AS, Mozaffarian D, Roger VL, Benjamin EJ, Berry JD, Blaha MJ, Dai S, Ford ES, Fox CS, Franco S, Fullerton HJ, Gillespie C, Hailpern SM, Heit JA, Howard VJ, Huffman MD, Judd SE, Kissela BM, Kittner SJ, Lackland DT, Lichtman JH, Lisabeth LD, Mackey RH, Magid DJ, Marcus GM, Marelli A, Matchar DB, McGuire DK, Mohler ER 3rd, Moy CS, et al: Heart disease and stroke statistics-2014 update: a report from the American Heart Association. Circulation 2014, 129(3):e28-e292.
2. Lopez AD, Mathers CD, Ezzati M, Jamison DT, Murray CJ: Global and regional burden of disease and risk factors, 2001: systematic analysis of population health data. Lancet 2006, 367(9524):1747-1757.

3. Kathiresan S, Srivastava D: Genetics of human cardiovascular disease. Cell 2012, 148(6):1242-1257.

4. Topol EJ, Smith J, Plow EF, Wang QK: Genetic susceptibility to myocardial infarction and coronary artery disease. Hum Mol Genet 2006, 15(Spec No 2):R117-R123.

5. Wang Q: Advances in the genetic basis of coronary artery disease. Curr Atheroscler Rep 2005, 7(3):235-241.

6. Girelli D, Martinelli N, Peyvandi F, Olivieri O: Genetic architecture of coronary artery disease in the genome-wide era: implications for the emerging "golden dozen" loci. Semin Thromb Hemost 2009, 35(7):671-682.

7. Consortium WTCC: Genome-wide association study of 14,000 cases of seven common diseases and 3,000 shared controls. Nature 2007, 447(7145):661-678.

8. Helgadottir A, Thorleifsson G, Manolescu A, Gretarsdottir S, Blondal T, Jonasdottir A, Sigurdsson A, Baker A, Palsson A, Masson G, Gudbjartsson DF, Magnusson KP, Andersen K, Levey Al, Backman VM, Matthiasdottir S, Jonsdottir T, Palsson S, Einarsdottir H, Gunnarsdottir S, Gylfason A, Vaccarino V, Hooper WC, Reilly MP, Granger CB, Austin H, Rader DJ, Shah SH, Quyyumi AA, Gulcher JR, et al: A common variant on chromosome 9p21 affects the risk of myocardial infarction. Science 2007, 316(5830):1491-1493.

9. Lee JY, Lee BS, Shin DJ, Woo Park K, Shin YA, Joong Kim K, Heo L, Young Lee J, Kyoung Kim Y, Jin Kim Y, Bum Hong C, Lee SH, Yoon D, Jung Ku H, Oh IY, Kim BJ, Lee J, Park SJ, Kim J, Kawk HK, Lee JE, Park HK, Nam HY, Park HY, Shin C, Yokota M, Asano H, Nakatochi M, Matsubara T, Kitajima H, et al: A genome-wide association study of a coronary artery disease risk variant. J Hum Genet 2013, 58(3):120-126.

10. McPherson R, Pertsemlidis A, Kavaslar N, Stewart A, Roberts R, Cox DR, Hinds DA, Pennacchio LA, Tybjaerg-Hansen A, Folsom AR, Boerwinkle E, Hobbs $\mathrm{HH}$, Cohen JC: A common allele on chromosome 9 associated with coronary heart disease. Science 2007, 316(5830):1488-1491.

11. Samani NJ, Erdmann J, Hall AS, Hengstenberg C, Mangino M, Mayer B, Dixon RJ, Meitinger T, Braund P, Wichmann HE, Barrett JH, Konig IR, Stevens SE, Szymczak S, Tregouet DA, lles MM, Pahlke F, Pollard H, Lieb W, Cambien F, Fischer M, Ouwehand W, Blankenberg S, Balmforth AJ, Baessler A, Ball SG, Strom TM, Braenne I, Gieger C, Deloukas P, et al: Genomewide association analysis of coronary artery disease. N Engl J Med 2007, 357(5):443-453.

12. Schunkert $H$, Konig IR, Kathiresan S, Reilly MP, Assimes TL, Holm H, Preuss M, Stewart AF, Barbalic M, Gieger C, Absher D, Aherrahrou Z, Allayee H, Altshuler D, Anand SS, Andersen K, Anderson JL, Ardissino D, Ball SG, Balmforth AJ, Barnes TA, Becker DM, Becker LC, Berger K, Bis JC, Boekholdt SM, Boerwinkle E, Braund PS, Brown MJ, Burnett MS, et al: Large-scale association analysis identifies 13 new susceptibility loci for coronary artery disease. Nat Genet 2011, 43(4):333-338.

13. Takeuchi F, Yokota M, Yamamoto K, Nakashima E, Katsuya T, Asano H, Isono M, Nabika T, Sugiyama T, Fujioka A, Awata N, Ohnaka K, Nakatochi M, Kitajima H, Rakugi H, Nakamura J, Ohkubo T, Imai Y, Shimamoto K, Yamori Y, Yamaguchi S, Kobayashi S, Takayanagi R, Ogihara T, Kato N: Genome-wide association study of coronary artery disease in the Japanese. Eur J Hum Genet 2012, 20(3):333-340.

14. Wang F, Xu CQ, He Q, Cai JP, Li XC, Wang D, Xiong X, Liao YH, Zeng QT, Yang YZ, Cheng X, Li C, Yang R, Wang CC, Wu G, Lu QL, Bai Y, Huang YF, Yin D, Yang Q, Wang XJ, Dai DP, Zhang RF, Wan J, Ren JH, Li SS, Zhao YY, Fu FF, Huang Y, Li QX, et al: Genome-wide association identifies a susceptibility locus for coronary artery disease in the Chinese Han population. Nat Genet 2011, 43(4):345-349.

15. Assimes TL, Knowles JW, Basu A, Iribarren C, Southwick A, Tang H, Absher D, Li J, Fair JM, Rubin GD, Sidney S, Fortmann SP, Go AS, Hlatky MA, Myers RM, Risch N, Quertermous T: Susceptibility locus for clinical and subclinical coronary artery disease at chromosome 9p21 in the multi-ethnic ADVANCE study. Hum Mol Genet 2008, 17(15):2320-2328.

16. Schunkert $H$, Gotz A, Braund P, McGinnis R, Tregouet DA, Mangino M, Linsel-Nitschke P, Cambien F, Hengstenberg C, Stark K, Blankenberg S, Tiret L, Ducimetiere P, Keniry A, Ghori MJ, Schreiber S, El Mokhtari NE, Hall AS, Dixon RJ, Goodall AH, Liptau H, Pollard H, Schwarz DF, Hothorn LA, Wichmann HE, Konig IR, Fischer M, Meisinger C, Ouwehand W, Deloukas P, et al: Repeated replication and a prospective meta-analysis of the association between chromosome 9p21.3 and coronary artery disease. Circulation 2008, 117(13):1675-1684. 
17. Shen GQ, Li L, Rao S, Abdullah KG, Ban JM, Lee BS, Park JE, Wang QK: Four SNPs on chromosome 9p21 in a South Korean population implicate a genetic locus that confers high cross-race risk for development of coronary artery disease. Arterioscler Thromb Vasc Biol 2008, 28(2):360-365.

18. Zhou L, Zhang X, He M, Cheng L, Chen Y, Hu FB, Wu T: Associations between single nucleotide polymorphisms on chromosome 9p21 and risk of coronary heart disease in Chinese Han population. Arterioscler Thromb Vasc Biol 2008, 28(11):2085-2089.

19. Virani SS, Brautbar A, Lee W, MacArthur E, Morrison AC, Grove ML, Nambi V, Frazier L, Wilson JM, Willerson JT, Boerwinkle E, Ballantyne CM: Chromosome 9p21 single nucleotide polymorphisms are not associated with recurrent myocardial infarction in patients with established coronary artery disease. Circ J 2012, 76(4):950-956.

20. Horne BD, Carlquist JF, Muhlestein JB, Bair TL, Anderson JL: Association of variation in the chromosome 9p21 locus with myocardial infarction versus chronic coronary artery disease. Circ Cardiovasc Genet 2008, 1(2):85-92.

21. Doria A, Wojcik J, Xu R, Gervino EV, Hauser TH, Johnstone MT, Nolan D, Hu $\mathrm{FB}$, Warram JH: Interaction between poor glycemic control and 9p21 locus on risk of coronary artery disease in type 2 diabetes. JAMA 2008, 300(20):2389-2397.

22. Hu WL, Li SJ, Liu DT, Wang Y, Niu SQ, Yang XC, Zhang Q, Yu SZ, Jin L, Wang XF: Genetic variants on chromosome 9p21 and ischemic stroke in Chinese. Brain Res Bull 2009, 79(6):431-435.

23. Thygesen K, Alpert JS, White HD: Universal definition of myocardial infarction. Eur Heart J 2007, 28(20):2525-2538.

24. World Health Organisation: Definition Diagnosis and Classification of Diabetes Mellitus and its Complications: Report of a WHO Consultation. Part 1. Diagnosis and Classification of Diabetes Mellitus. Geneva: WHO; 1999.

25. Bell PA, Chaturvedi S, Gelfand CA, Huang CY, Kochersperger M, Kopla R, Modica F, Pohl M, Varde S, Zhao R, Zhao X, Boyce-Jacino MT, Yassen A: SNPstream UHT: ultra-high throughput SNP genotyping for pharmacogenomics and drug discovery. Biotechniques 2002, Suppl:70-72. 74, 76-77.

26. Lou XY, Chen GB, Yan L, Ma JZ, Zhu J, Elston RC, Li MD: A generalized combinatorial approach for detecting gene-by-gene and gene-byenvironment interactions with application to nicotine dependence. Am J Hum Genet 2007, 80(6):1125-1137.

27. Andersson T, Alfredsson L, Kallberg H, Zdravkovic S, Ahlbom A: Calculating measures of biological interaction. Eur J Epidemiol 2005, 20(7):575-579.

28. Motterle A, Pu X, Wood H, Xiao Q, Gor S, Ng FL, Chan K, Cross F, Shohreh B, Poston RN, Tucker AT, Caulfield MJ, Ye S: Functional analyses of coronary artery disease associated variation on chromosome 9p21 in vascular smooth muscle cells. Hum Mol Genet 2012, 21(18):4021-4029.

29. Xie F, Chu X, Wu H, Sun W, Shen M, Yang L, Wang Y, Shi J, Huang W: Replication of putative susceptibility loci from genome-wide association studies associated with coronary atherosclerosis in Chinese Han population. PLOS ONE 2011, 6(6):e20833.

30. Go AS, Mozaffarian D, Roger VL, Benjamin EJ, Berry JD, Blaha MJ, Dai S, Ford ES, Fox CS, Franco S, Fullerton HJ, Gillespie C, Hailpern SM, Heit JA, Howard VJ, Huffman MD, Judd SE, Kissela BM, Kittner SJ, Lackland DT, Lichtman JH, Lisabeth LD, Mackey RH, Magid DJ, Marcus GM, Marelli A, Matchar DB, McGuire DK, Mohler ER 3rd, Moy CS, et al: Executive summary: heart disease and stroke statistics-2014 update: a report from the American Heart Association. Circulation 2014, 129(3):399-410.

31. Yusuf S, Hawken S, Ounpuu S, Dans T, Avezum A, Lanas F, McQueen M, Budaj A, Pais P, Varigos J, Lisheng L: Effect of potentially modifiable risk factors associated with myocardial infarction in 52 countries (the INTERHEART study): case-control study. Lancet 2004, 364(9438):937-952.

32. Fox CS: Cardiovascular disease risk factors, type 2 diabetes mellitus, and the Framingham Heart Study. Trends Cardiovasc Med 2010, 20(3):90-95.

33. Wen J, Ronn T, Olsson A, Yang Z, Lu B, Du Y, Groop L, Ling C, Hu R: Investigation of type 2 diabetes risk alleles support CDKN2A/B, CDKAL1, and TCF7L2 as susceptibility genes in a Han Chinese cohort. PLOS ONE 2010, 5(2):e9153.

34. Krishnamurthy J, Ramsey MR, Ligon KL, Torrice C, Koh A, Bonner-Weir S, Sharpless NE: p16INK4a induces an age-dependent decline in islet regenerative potential. Nature 2006, 443(7110):453-457.

35. Rane SG, Dubus P, Mettus RV, Galbreath EJ, Boden G, Reddy EP, Barbacid M: Loss of Cdk4 expression causes insulin-deficient diabetes and Cdk4 activation results in beta-islet cell hyperplasia. Nat Genet 1999, 22(1):44-52
36. Tsutsui T, Hesabi B, Moons DS, Pandolfi PP, Hansel KS, Koff A, Kiyokawa H: Targeted disruption of CDK4 delays cell cycle entry with enhanced p27 (Kip1) activity. Mol Cell Biol 1999, 19(10):7011-7019.

37. Dechamethakun S, Ikeda S, Arai T, Sato N, Sawabe M, Muramatsu M: Associations between the CDKN2A/B, ADTRP and PDGFD Polymorphisms and the Development of Coronary Atherosclerosis in Japanese Patients. J Atheroscler Thromb 2014, [Epub ahead of print].

38. Tayebi N, Ke T, Foo JN, Friedlander Y, Liu J, Heng CK: Association of single nucleotide polymorphism rs6903956 on chromosome 6p24.1 with coronary artery disease and lipid levels in different ethnic groups of the Singaporean population. Clin Biochem 2013, 46(9):755-759.

39. Lu X, Wang L, Chen S, He L, Yang X, Shi Y, Cheng J, Zhang L, Gu CC, Huang J, Wu T, Ma Y, Li J, Cao J, Chen J, Ge D, Fan Z, Li Y, Zhao L, Li H, Zhou X, Chen L, Liu D, Duan X, Hao Y, Lu F, Liu Z, Yao C, Shen C, Pu X, et al: Genome-wide association study in Han Chinese identifies four new susceptibility loci for coronary artery disease. Nat Genet 2012, 44(8):890-894.

40. Guo CY, Gu Y, Li L, Jia EZ, Li CJ, Wang LS, Yang ZJ, Cao KJ, Ma WZ: Association of SNP rs6903956 on chromosome 6p24.1 with angiographical characteristics of coronary atherosclerosis in a Chinese population. PLOS ONE 2012, 7(8):e43732.

41. Lupu C, Zhu H, Popescu NI, Wren JD, Lupu F: Novel protein ADTRP regulates TFPI expression and function in human endothelial cells in normal conditions and in response to androgen. Blood 2011, 118(16):4463-4471.

\section{doi:10.1186/1471-2261-14-170}

Cite this article as: Zhang et al:: Interaction of type 2 diabetes mellitus with Chromosome 9p21 rs10757274 polymorphism on the risk of myocardial infarction: a case-control study in Chinese population. BMC Cardiovascular Disorders 2014 14:170.

\section{Submit your next manuscript to BioMed Central and take full advantage of:}

- Convenient online submission

- Thorough peer review

- No space constraints or color figure charges

- Immediate publication on acceptance

- Inclusion in PubMed, CAS, Scopus and Google Scholar

- Research which is freely available for redistribution

Submit your manuscript at www.biomedcentral.com/submit
C Biomed Central 